\title{
Chief scientist quits California stem-cell agency
}

The California Institute for Regenerative Medicine (CIRM) in San Francisco is again under the microscope, following the resignation of its chief scientific officer and a call for its restructuring.

Marie Csete, a doctor and stem-cell biologist, has resigned from CIRM's top science job, effective from 1 August. The move leaves CIRM without medical leadership as it prepares to issue US\$210 million in grants for stemcell research that aim towards clinical trials. "When it became clear to me that my considered clinical advice was not respected, I concluded that it made no sense for me to stay at CIRM," she says.

When Csete left Emory University in Atlanta, Georgia, to join CIRM in March 2008, she gave up her lab and divorced her husband John Doyle. He is a professor at the California Institute of Technology in Pasadena, an institution she would be inviting to apply for research funding and so needed to avoid contravening state conflict-of-interest laws. "We were willing to sacrifice a lot for me to be in a position to make a positive impact at CIRM," she says. "I wanted to see it to the end."

Her accomplishments at the agency include restructuring CIRM's grant programmes, cultivating relationships with grantees and laying the groundwork for international collaborations. "Her medical and scientific experience made her a superb proponent of CIRM's main mission, which is to make stem cells medically useful," says Jeanne Loring, a stem-cell researcher at the Burnham Institute in La Jolla, California. "It won't be easy to replace her."

In a message to staff, CIRM president Alan Trounson praised Csete's "highly valuable contributions to our science operations".

Csete says she hopes her leaving will mark "a new start" for the agency. "I had tried everything I could to change what I think needed to change from the inside, and that was not going to happen," she says. "I felt I would have more impact by stepping away and advising the leadership of the board on my way out about ways to revise the structure and management of the agency to make it more optimal."

Csete would not provide details on what changes she feels are needed. But her frustration echoes previous tensions over leadership structure that led in part to the early departure of CIRM's first president,
Zach Hall, in 2007. The agency's structure is spearheaded by Robert Klein, CIRM's architect, and includes Trounson and a 29-member governing board.

Last year, two state senators asked California's bipartisan, independent oversight agency, the Little Hoover Commission, to study CIRM's governance.

"I felt I would

have more impact

by advising the

leadership of the board on my way

out." - Marie Csete

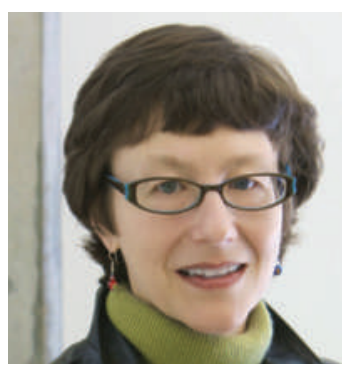

On 25 June, the commission reported that CIRM's governance structure "locks in inefficiencies" and "inhibits CIRM's ability to adjust to changing scientific and political landscapes". The commission recommended that CIRM downsize its board to 15 members, add members without ties to CIRM grantees, boost the efficiency and transparency of grant reviews, clarify the overlapping roles of chair and president, and "create succession plans for board leadership", a reference to Klein's statement that he will leave the agency next year.

Hall says the recommendations are "useful, thoughtful and should be seriously considered", but says "the leadership of the agency has taken a position that any change at all threatens the entirety of stemcell research, and that's unfortunate".

Indeed, CIRM said in a statement that it was disappointed with the Little Hoover Commission's recommendations, which would "slow the agency's progress toward cures”. But CIRM board member Jeff Sheehy wrote on a blog that CIRM's "knee jerk" reaction, delivered in a statement dated 24 June - before the Hoover group released its final report - "suggests a renegade agency outside the control of its board or the state of California".

The report is unlikely to spur immediate change, as the state legislature, which would need to enact many of the recommendations, is preoccupied with California's budget crisis.

Erika Check Hayden

\section{SWAPSHOT
Vanishing neadows}

Seagrass meadows around the world are in dire

shape, according to the first comprehensive

global assessment of these economically and

biologically essential areas.

More than a quarter of all seagrass

meadows have disappeared in the

past 130 years, says a new synthesis

of quantitative data from 215 sites

(M. Waycott et al. Proc. Natl Acad. Sci.

USA doi:10.1073/pnas.0905620106;

2009). The rate of decline has grown

from less than $1 \%$ per year before

1940 , to $7 \%$ per year since 1990 .

As well as supporting wildlife such

as dugong (Dugong dugon, right)

and green turtles (Chelonia mydas)

seagrass meadows also serve as

a vital nursery for fish, supporting

populations for coral reefs and

commercial fisheries.

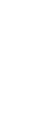

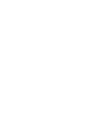

